\title{
Sob o signo da História: resposta a meus comentadores
}

\author{
Eduardo Neiva \\ University of Alabama at Birmingham \\ Universidade Federal Fluminense
}

Se em geral cada comentário adiciona um suplemento ao texto lido, toda crítica é um deslocamento. Assim os comentários críticos serão sempre uma manifestação intelectual superior, pois apontam o que não fora a princípio percebido. Por isso, agradeço de coração a meus críticos - Elias Thomé Saliba, Ciro Flamarion Cardoso, Ulpiano Bezerra de Meneses, Eduardo Peñuela Cañizal e Lucrécia D'Alessio Ferrara - pelo exercício de inteligência e generosidade.

Para responder-thes, preciso antes de mais nada reafirmar as pressuposições do artigo "Imagem, história e semiótica". Esse texło é de fato um posicionamento radicalmente externo à prática da história da arte. Não é um escrito historiográfico de cunho teórico e metodológico. Realmente Ciro Flamarion tem toda razão. Meu texto quer apenas estabelecer as condições para um diálogo com as idéias correntes entre os historiadores. Ao comissionarme para escrever o artigo de fundo deste número dos Anais do Museu Paulista, certamente o Professor Ulpiano Bezerra de Meneses sabia de meus propósitos e limites.

Não posso, nem quero discutir o caminho mais eficaz para a historiografia, porque não sou historiador e porque acho que, se fosse, apenas estaria reafirmando regras-de-ofício que são para mim o seu maior impasse. É natural que a prática de um ofício recuse-se a padecer de dúvidas. Tenho várias dúvidas e questões para apresentar aos historiadores.

Tudo o que está no artigo "Imagem, história e semiótica" parte de um juízo. Até agora fracassaram as tentativas de pensar a imagem a partir do 
1. Estou ciente de que os nexos entre história e biografia são bem mais complexos do que acabo de dizer. Não é o suficiente optar entre biografia e descrição de movimentos coletivos. Hoje, para uma historiografia que vive a exacerbação da crise, o recurso à narração biográfica pode ser uma alternativa encantadora, precisamente pelos limites que a definem (Levi 1989: 1325). que the é externo. Ainda que seja factivel apreender categorias sociológicas, psicológicas - e por que não históricas ? - na análise de imagens, trata-se de abordagens insuficientes. De uma maneira geral, reafirmo que a consideração dos princípios formadores da imagem tem o que ensinar aos historiadores, da mesma maneira que as interpretações historiográficas contribuíram para o entendimento das produções visuais. Afinal se não pudéssemos contextualizar uma imagem, de maneira historicamente precisa, não seríamos capazes de ir além da mera percepção.

Mas, por que é preciso ir além da história? Ora, se os historiadores não pensarem o que tem permitido as análises históricas, estarão condenados a princípios cognitivos que thes parecem óbvios e indiscutiveis, mas que os levam aos mesmos caminhos, através das rolas de sempre. A história da arte tem lá a sua história. Comecemos por examiná-la.

\section{A história da história da arte}

A trajetória histórica da história da arte é bem nítida. $O$ legado nos vem de Giorgio Vasari (151 1-1574) e seu livro Le vite de' più eccellenti architetti, pittori et scultori italiani (l a. edição:1550, 2a. edição, aumentada: 1568). O livro de Vasari era uma série linear e cronológica de biografias que continha em sua seqüência algo mais do que o mero relato das vidas de artistas. $O$ tempo histórico desdobrava-se numa indicação de que a cronologia nos levava a uma culminação, ao mesmo tempo histórica e artística. Mas há aqui uma constelação de problemas. Não só pelas imprecisões que o encantamento de Vasari por Michelangelo produzia, mas também porque as biografias eram a expressão de heróis culturais parciais1: a seqüência histórica caminhava para a plenitude expressa em termos estéticos e biográficos pelo último artista: Michelangelo Buonarotti (1475-1564).

Na historiografia que Vasari inicia, a regra-de-ofício é essencializar os acontecimentos biográficos. A história da arte reduz-se a uma projeção das características pessoais dos artistas.Dessa maneira, a história da arte revela-se a partir do desdobramento das possibilidades artísticas que os criadores materializavam. Na sua origem, a história da arte é uma gestação endógena que se concebe imaculada em si mesma. Nesse momento não há sequer uma preocupação com a contextualização social. Para a história da arte basta-the o juízo normativo do intérprete gue se apresenta mais como um crítico do que efetivamente um historiador. É igualmente claro que a contextualização restrita a biografias haveria de ser insuficiente. Mais adiante, a história da arte exigirá uma interpretação culturalista que situe a arte numa ambiência social sem a qual - relato de incidentes biográficos se dissolve em simples anedotário. Estamos numa zona fronteiriça onde já temos historiografia da arte, ainda que parcamente realizada.

Considerada como saber objetivo e legítimo, a história da arte efetiva-se a partir dos argumentos kantianos que recusam a idéia de que a criação 
esteja presa aos preceitos normativos de representação imitativa da natureza. A história da arte só é possivel quando a arte se liberta da categoria de mimesis. Mais do que uma fidelidade ao que vem do exterior, o que importa é a potência subjetiva da criação. Didier-Huberman (1989) afirma ser a história da arte pós-vasariana uma espécie de kantismo implícito.Segundo Didier-Huberman, a história da arte deriva-se das condições criadas por Kant ao recusar o dogma principal da tradição humanística, que é conjunção indissolúvel entre a mimesis como princípio estético e a expressão necessária da Beleza. A faculdade de conhecimento da natureza e o juízo artístico estão separados, pois nesse momento distinguem-se "a universalidade objetiva da razão pura e a universalidade subjetiva das obras do gênio" (Didier-Huberman 1989:47). Livre da obrigação de julgar as obras de arte como uma presumida imitação da natureza, a interpretação estéfica caminhará para o entendimento da criação em relação às condições oferecidas pela época que as produziu. Agora, a história da arte efetivamente existe, mas a sua divida para com o kantismo há de persegui-la como à própria sombra.

Ao expor minha avaliação a propósito da história da arte, tive o cuidado de apresentar, com o máximo detalhe possível, aquilo que me parecia ser a mais límpida e competente expressão do kantismo, que, como acabamos de ver, é a condição subjacente e implícita a toda historiografia da arte. A predominância da iconologia de Panofsky não é acidental, nem insignificante. Quando Ciro Flamarion diz que meus "únicos exemplos concretos são tomados de análises feitas pela iconologia panosfkiana", ele não percebe o que há de fundamental na minha escolha por Panofsky. Acho que Ciro não tem como negar que a história da arte contemporânea deve imensamente à visão metodológica de Panofsky (Holly 1984:158). Em nenhum outro autor de importância para a história da arte, a ação do kantismo é tão evidenciada. Independente de minha admiração por sua sutileza, precisão e saber iconográfico, Panofsky é o lugar-tenente do kantismo na história da arte recente. Ao falar de Panofsky, eu falava, de fato, das restrições e do alcance da história da arte como um todo.

\section{Críticas divergentes à iconologia}

Logo adiante, Ciro Flamarion acrescenta: "ora, independente de outras críticas que se the façam, é sabido que uma das limitações principais da iconologia é seu campo estritamente circunscrito a certas sociedades ocidentais e a um determinado recorte temporal". Aqui Ciro comete um equívoco factual, que não sei se atribuo ao desconhecimento ou à pressa de inferir que a iconologia sirva apenas para a arte ocidental presumidamente o Renascimento ${ }^{2}$.

Há mais de trinta anos, nas conferências Lugard de 1961, Vingi Grottaelli advogou intensamente a aplicação da iconologia de Panofsky à arte africana. É bem verdade que, no caso da arte africana, alguns cuidados deve-
2. No primeiro capítulo de Significado nas artes visuais, Panofsky (1976) situa a arte egípcia como um momento na história da representação das proporções humanas. Ciro Flamarion não faz sequer a mínima referência a essa contribuição de Panofsky. 
riam ser tomados. Panofsky falava no uso de textos literários, artísticos e cientificos para a identificação dos elementos da imagem renascentista. Para o caso da arte africana, o mesmo seria perfeitamente alcançável através do recurso a práticas culturais registradas pela tradição oral do grupo social onde a obra foi gerada.

As sugestões de Grottanelli estão materializadas no estudo que Robert T. Soppelsa (1988) fez da escultura Akan, encontrável no sudeste da Costa do Marfim. Passo a passo, Soppelsa segue as indicações metodológicas de Panofsky, o que transforma esse artigo simultaneamente num teste - que poderia falsificar a iconologia enquanto método - e numa análise concreta da escuttura africana. Assim num conjunto de esculturas africanas, graças à memória dos membros mais velhos do grupo, Soppelsa identifica cada imagem de morto. Mas esse elemento não pode ser tomado isoladamente. A representação nas esculturas adquire um outro sentido, se considerarmos a importância cultural da realeza e dos antepassados para a cultura Akan. O que justifica a produção das esculturas é prioritariamente o estatuto políico e social da pessoa representada, e não os seus traços fisionômicos. O lugar social define o individuo: pois o sentido de sua existência é dado por sua inscrição na hierarquia social. $O$ que então querem dizer as representações desses mortos? Através delas, continuaria a relação entre vivos e mortos. E mais: hierarquicamente superiores, os mortos conduzem os vivos (Soppelsa 1988:152). As esculturas Akan são objetos tão significativos culturalmente quantos as obras do Renascimento. E mais: a iconologia serve como método explicativo para as artes não ocidentais.

Desde que a interpretação seja propriamente contextualizada, o método iconológico será útil. A tradição oral e as funções tradicionais dos objetos culturais são dados inestimáveis para o intérprete da arte africana. A obra é um sintoma da cultura. Há, entre a obra e a cultura, um processo de iluminação mútua. Após observar o cuidado que Soppelsa toma para evitar interpretações etnocêntricas, devo apontar que Ciro Flamarion erra ao julgar que a iconologia só serve para a interpretação de um certo período da arte ocidental. Não consigo entender porque Ciro Flamarion circunscreve o método iconológico a um horizonte tão determinado historicamente. Não há traços deterministas na herança que Panofsky recebe de Cassirer. As formulações de inspiração kantiana têm conseqüências para a história da arte, mas não aquelas que Flamarion sugere. Os a priori, que definem todo o argumento kantiano, são apenas condições para alguma coisa; trata-se de formas ordenadoras que moldam a experiência, mas que não trazem consigo conteúdos determinados. Como falei no artigo anterior dos a priori - espaço e tempo - expostos na seção Estética Transcendental da Crítica da Razão Pura (1781), apresentarei agora um outro a priori - o imperativo categórico - que reina na Crítica da Razão Prática (1788).

Kant estabelece o imperativo categórico como um princípio para toda e qualquer ação ética. Trata-se de um fundamento racional que deve estar presente como condição no horizonte ético; é um "produto puramente racional, agência historicamente indeterminada" (Stern 1986:312). Portanto, Kant pede que as ações humanas sejam universais, o que implica a transcendência de interesses estritamente individuais. Não há aqui nenhum conteúdo moral especí- 
fico, apenas um princípio geral, ou, se preferirmos, uma fórmula expressa pela regra que exige de qualquer ação uma validade para todos os homens e todos os momentos.

O a priori é uma lei que se quer universal. Assim, transferindo esse argumento para a análise das obras de arte, podemos dizer que uma teoria da arte de inspiração kantiana e a priori não traz consigo quaisquer leis estéticas normativas. $E$, portanto, pode servir a qualquer forma histórica. O que considero discutível na tradição kantiana certamente não é o que Ciro Flamarion qualificaria de questionável.

Ao postular o imperativo categórico como a priori, Kant sintetizou as tendências até então dominantes na teoria política tradicional, tudo sublinhado por uma concepção finalista de história. Kant recusou-se a optar seja por um modelo idealizante da vida social ou por uma perspectiva empírica, onde predominaria o interesse situacional. Kant está entre Platão e Maquiavel (Kein 1989:326). Em Kant, o curso da história demonstra a conciliação entre a dinâmica empírica dos interesses em conflito e uma perspectiva moral teleológica e universalizante. O kantismo acredita que a história humana caminha para um fim determinado, ainda que as leis formadoras do caminho sejam desconhecidas pelos homens (Kant 1959:29). Tal crença é o que justifica a história como campo de estudos e disciplina. As leis da história aguardam apenas a sua descoberta. É preciso olhar para o passado. Na concepção kantiana da história como simultaneamente moral e teleológica, é que encontraremos a motivação inicial para a investigação histórica. Em geral, a história recebeu do kantismo dois de seus traços fundamentais: a noção de que o movimento histórico é seqüencial e linear, e também a idéia de contrato que, através das convenções, regeria os acontecimentos passados, presentes e fưuros. Os a priori têm uma nítida vinculação histórica. Podem ser históricos porque se apresentam como um substrato antropológico, pois Kant concebera a história humana como a realização de um plano oculto criador das relações políticas, da ordem moral e da cultura.

É devido à influência kantiana que a história em geral, e mais especificamente a história da arte, haverá de receber, conforme disse Argan (1992:16), sua qualificação de empreendimento "quase antropológico". Kant imaginava a história como o equilíbrio entre movimento finalista e contratualismo. O que é bem claro quando encontramos as profecias kantianas que imaginavam a conciliação inevitável dos conflitos nacionais através de uma liga das nações, geradora da paz universal e sobreposta às particularidades e interesses concretos de cada grupo social. Além dos contratos nacionais específicos de cada grupo social, existirá um contrato mais geral e ainda mais abrangente, de teor cosmopolita. Assim Kant entende como história: nosso destino comum e inevitável superará sifuações particulares. $O$ que só acontece quando nos comprometemos com toda a humanidade.

Não há nenhuma contradição entre a história como finalidade de cunho historicista e a ação contratualista das convenções. São os dois lados de uma mesma moeda corrente entre os historiadores, ainda que hoje prevaleça menos o modelo historicista do que a história como uma espécie de antropologia do passado, cujo melhor exemplo é o trabalho de Carlo Ginzburg. 
3. Qualquer um que leia os comentários críticos mais recentes, feitos em revista de história, sobre os livros de Ginzburg notará o espanto que ele provoca: muitas vezes, é verdade, misturado à admiração (Burke 1990, Blazes 1991, Herlihy 1991, de Moles 1990, Martin 1992, Nugent 1992 e Schutte 1992). A variedade de temas e métodos que ele cobre em seus livros beira o escândalo. Luria (1986) acha que o encanto do paradoxo define Carlo Ginzburg. Para mim, fica a impressão de que é precisamente o fato de estar aberto ao que vem além das fronteiras estritamente disciplinares da história aquilo que faz de Ginzburg um caso especial, uma altemativa instigante na historiografia recente.

4. Os princípios convencionalistas dominam dois estudos importantes de Carlo Ginzburg (1989:60-95): "The high and the low: the theme of forbidden knowledge in the sixteenth and seventeenth centuries" e "Titian, Ovid and sixteenth century codes for erotic illustration". No primeiro artigo, predomina uma ma-
Dentre os meus críticos, quem percebeu essa tensão foi Elias Saliba, quando diz que existe entre os historiadores uma tradição muito forte de cunho historicista, que os obriga a se desdobrarem " num esforço legítimo de situar a obra no sistema unificador que a produziu". E tudo vem embrulhado numa concepção linear de temporalidade. Para superá-la, o historiador desfaz-se num estorço tenaz, mas os pressupostos convencionalistas continuam se espalhando pelas análises historiográficas.

Sob a sombra de Kant; a história pôde passar do finalismo historicista à análise contextualizada das convenções passadas. É claro que reconheço a ação das convenções na arte e na vida social como um todo, apenas não as considero como o único processo presente nas imagens. Há no convencionalismo, admitido sem questionamento por um horizonte de historiadores, uma teoria dos signos que precisa ser reformulada criticamente. $O$ resultado teria que ser aquele apontado por Saliba: reduzem-se o aleatório e a incerteza que são os atributos mais persistentes da história humana.

$\bigcirc$ artigo "Imagem, história e semiótica" quer apresentar uma alternativa à predominância do convencionalismo que infesta não apenas a história. $\bigcirc$ convencionalismo é também um programa dogmático em outras ciências humanas e sociais. Novamente, Saliba identifica o ponto nevrálgico de minha proposta: sugerir uma teoria da representação que, escapando dos limites do convencionalismo, seja capaz de capturar a variedade e a complexidade da experiência humana. Lamento não poder oferecer caminhos e soluções imediatas para a prática dos historiadores. É curioso observar que Carlo Ginzburg3, um dos mais interessantes historiadores recentes, utilize a categoria de abdução - que é de teor estritamente semiótico, porém não convencionalista na sua análise do paradigma indiciário (Ginzburg 1989:96-125). Haverá, finalmente, uma alternativa à tirania do convencionalismo?

Ginzburg abraça uma teoria dos signos da maneira mais límpida. Talvez seja por isso que ele advirta os historiadores de que nunca poderiam abordar diretamente a realidade histórica (Ginzburg 1991:84). A interpretação histórica é sempre inferencial, ou seja hipotética. Mas, ser inferencial não significa estar isenta da tarefa de prova. Como toda interpretação, a história é, na sua origem, de natureza abdutiva. A história resulta do juízo não imediato feito a partir de momentos que estão distantes do historiador. Em si mesmo, o passado é tão inacessível quanto a coisa-em-si kantiana.

historiador só lida com representações que se oferecem ao seu olhar. Parece que a história pode enfim se aproximar de uma teoria dos signos, pois a abdução é uma etapa fundamental da atividade sígnica revelada pela teoria relacional de Charles Peirce, exposta com algum detalhe no artigo deste número, e de maneira ainda mais completa no livro Um inferno de espelhos: comunicação, cultura e mundo natural (Neiva 1992). Preciso acentuar, que um outro tipo de teoria dos signos insinua-se em Ginzburg, já que ele opta mais freqüentemente por uma antropologia do passado, de cunho simbólico e convencionalistá. Parece que a historiografia só é capaz de suportar uma semiótica desse tipo. 
De uma maneira geral, Ciro Flamarion pede restrições às abordagens que privilegiem os signos. Seus argumentos são brilhantes, porém insuficientes. A objeção inicial de Ciro parte da minha observação de que o programa de produção das imagens seja partilhado tanto por quem produziu a imagem como por quem a contempla. Em retrospecto, acho que deveria ter qualificado melhor como esse programa é partilhado. A crítica de Ciro Flamarion diz, corretamente, que o programa não é necessariamente comum a todos os atores sociais e que na maioria das vezes é compreensível apenas por uma parte do corpo social: o que presumo seja o criador è a elite educada para tal. A princípio nada tenho a me opor à idéia. Apenas gostaria de ir além pois meu crítico quer de mim mais radicalidade.

programa de produção pode ser perfeitamente inconsciente, e assim inacessivel para todos os atores sociais. Aí incluem-se o artista e também aqueles para quem a obra foi produzida. A imagem não é por tal razão menos eficaz. A idéia está claramente expressa na concepção culturalista da história da arte defendida por Panofsky: acredito que Ciro Flamarion não se oponha a ela, pois me parece ser um pressuposto de sua minuciosa análise da arte egípcia.

Existem leis implicitas gerando as manifestaçōes artísticas. Essas leis são o verdadeiro objeto do historiador que revelará as regras, os códigos cognitivos, as relações entre os objetos criados e sublinhados pela totalidade da cultura. Contemplar a superfície da imagem é insuficiente. Precisaríamos isolar as regras subjacentes à imagem. Um sistema de regras determina a presença básica da obra de arte (Holly 1984: 186). Mesmo que o historicismo teleológico possa ser abandonado por historiadores mais críticos, a história da arte, enquanto disciplina, presume que existam regras implicitas geradoras da obra e que são o verdadeiro objeto da historiografia.

Novamente, encontramos o veio convencionalista que até hoje tem dominado a história da arte. Para que exista uma perspectiva convencionalista, é preciso a ação do sistema da cultura. A cultura unifica a produção de imagens. A cultura é um a priori, que molda os sujeitos individuais, mas, por outro lado, o sistema das instituições culturais é uma espécie de sujeito unitário onipresente em toda e qualquer existência histórica.

convencionalismo tem um alto preço a pagar: os objetos de sua análise facilmente perdem o caráter individual e transformam-se em efeitos de uma enorme construção metafísica (Holly 1984:29). Daí ser pertinente a crítica que Ulpiano Bezerra de Meneses faz ao conceito de Kunstwollen, exposto inicialmente por Alois Riegl e retomado com modificações por Panofsky. Sem dúvida, Kunstwollen é uma hipótese idealista e rarefeita.

fantasma da teleologia retorna: se há inevitavelmente uma construção metafísica subjacente à histórica, por que excluir a possibilidade de uma seqüência linear no curso da história? $E$, também, como é possível abandonar a concretude e a singularidade exigidas pela interpretação historiográfica? As triz opositiva próxima do que fizeram as análises estruturalistas. No segundo artigo, a noção de código é prima da categoria de estrutura e sistema. 
alternativas são conflitantes. Como proceder? A resenha que. Otto Pächt (1956) escreveu sobre o livro de Panofsky Early Netherlandish Painting é a expressão desse temor.

Em Early Netherlandish Painting, Panofsky defende uma tese surpreendente. As pinturas dos irmãos Van Eyck, mais precisamente as de Jan Van Eyck, só aparentemente devem ser qualificadas de representações minuciosas e realistas. Seu naturalismo esconde laços simbólicos intrincados que corporificam conceitos teológicos. As representações teológicas, implícitas e subjacentes, conferem significado às pinturas. Na representação minuciosa de cenas burguesas, significados religiosos estariam ocultos e à espreita. Não bastaria assisfir à dança viva de luz e de minúcias estridentes presentes nos quadros de Van Eyck. Os quadros se prestam a uma sutil divulgação de idéias: são instrumentos de pregação. A pregação existe, mesmo que a mensagem tenha até sido insuficientemente clara para os atores sociais que viam as imagens. Por exemplo, o famoso retrato de Giovanni Arnolfini e Jeanne Cenami seria simultaneamente um duplo retrato e um certificado de casamento. Qual a outra justificativa para a assinatura no quadro que diz: "Johannes de Eyck fuit hic" Uan Van Eyck esteve aquil? Panofsky conclui que o pintor representa-se como uma testemunha do casamento. Outros detalhes são examinados por Panofsky como portadores de significados simbólicos: o casal Arnolfini está não numa sala de recepção, mas numa câmara nupcial; ali, os espelhos são expressão simbólica da pureza e o cão na frente dos retratados é a imagem codificada de fé marital. Assim Panofsky fala de um programa simbólico materializado nesse quadro, e que desfaz as fronteiras entre retrato e narrativa, arte sacra e profana (Panofsky 1953:205|. Temos então múltiplas conseqüências, tanto para uma avaliação específica das pinturas, como para a metodologia histórica em geral.

Panofsky fez mais do que redefinir as pinturas de Van Eyck. Os quadros deixam de ser avaliados como naturalistas: não há razão para considerátos representações do cotidiano. Queiramos ou não, o cotidiano estaria povoado de representações religiosas. Temos agora uma hipótese perturbadora. Principalmente quando lemos em Panofsky a defesa de que existe na ordem da cultura uma prática não evidenciável, e que nem assim é menos importante. A prática está ali nas formas visuais. Como é possivel desconhecê-las? O mais surpreendente é que Panofsky já fizera tal proposta nos anos vinte, supondo regras implícitas que unificavam uma variedade de produções intelectuais historicamente contemporâneas, fossem elas filosóficas, artísticas, científicas, ou religiosas. Afinal, era a tese de A perspectiva como forma simbólica (1975).

Para Pächt, o caráter presumidamente inconsciente do programa simbólico é o seu principal problema. O simbolismo oculto na obra de arte seria incongruente com o ato de criação que passaria, então, a ser simultaneamente produto de uma estrutura racional e de uma estruturação irracional, "cada uma reinvindicando para si a captura da essência do fenômeno artístico e a sua compreensão" (Pächt 1956:276). A confusão é, portanto, inevitável. Precisamos tomar muito cuidado. O planejamento alegórico, complexo e sofisticado dos quadros dos Van Eyck pode bem ser uma projeção voluntarista de Panofsky. Só seria o contrário se não houvesse a menor incompatibilidade entre os quadros 
pintados e o ambiente vivido pelos Eyck, entre as formas visuais e a expressão neutralizada das figuras, que seriam apenas o resultado da postura distanciada do artista face ao que ele escolhera representar no microcosmo da natureza. Resíduos extra-semióticos estabeleceriam, finalmente, o sentido da imagem enquanto signo.

Pächt critica Panofsky indo da vida aos signos, enquanto que a argumentação de Ciro Flamarion vai dos signos à vida. No final de tudo, veremos como as críticas de Ciro defendem de maneira involuntária uma semiótica que não ousa dizer o próprio nome.

O pouco que conheço da civilização egípcia não me permite discutir em detalhe os argumentos de Ciro Flamarion. Mesmo assim, lendo-os fiquei com a impressão de que eles confirmam a hipótese subjacente ao meu artigo. No meu texto, defendo a idéia de que, por serem ações, os signos terão uma constituição fatalmente parcial: toda ação é - em si mesma - localizada.

Quando Ciro Flamarion aponta que a unidade cultural presumida por Panofsky não é universalizável, que existem exemplos de sistemas parciais, facilmente identificáveis na civilização egípcia, tudo me parece a confirmação do modelo aproximativo e localista de teoria dos signos que advogo no artigo. Para mim, o convencionalismo substancializado da iconologia é indefensável. Não me encanta o privilégio que o neo-kantismo de Cassirer concede à linguagem. Em Panofsky, a idéia de que as imagens ilustrem textos é apenas uma variante desse paradigma incompleto.

Mas não concordo com o pressuposto de que o atributo parcial e localista dos signos os qualifique, para usar os termos de Ciro Flamarion, como meros signos que achatam o mundo e a totalidade da experiência. Afinal, se, na civilização egípcia, a arte monumental era acessivel a uma parte ínfima de seus atores sociais, isso não a invalida como um agregado de signos agindo e construindo a interação humana. A escrita egípcia era também compreensível apenas para um extrato reduzido da sociedade: o que não a desqualifica como elemento definidor da unidade cultural no Egito Antigo (Baines 1983).

A partilha de signos toma várias formas. Devemos entendêtla com precisão. Caso contrário, corremos o risco de uma interpretação anacrônica, feita de um ponto de vista externo ao que acontecia efetivamente no Egito antigo. Enquanto ação, os signos têm o sentido de seu uso já que a prática consensual e contratualística - que informa a ideologia e as formações sociais burguesas - é apenas um caso particular de uso, provavelmente estranho ao Egito dos Faraós. Agora, devemos nos perguntar qual é então o sentido de uma escrita feita exclusivamente para tão poucos que nem sequer eram o topo do estrato social, pois os escribas formavam, de fato, "uma sub-elite" (Baines 1983).

A escrita egípcia é bem distinta dos ideogramas analógicos orientais5. É razoável supor que não tenha sido feita com propósitos representativos (Baines 1989:471). Pelo menos em sua concepção original, a função das representações hieroglíficas transcendia a propósitos comunicativos. A escrita fora feita para marcar propriedade. Dai certamente advém o seu caráter cifrado. Nesse caso, se falarmos em controle, será de cunho administrativo e não político, como Ciro Flamarion chega a sugerir.
5. Os ideogramas japoneses são tão im penetráve is quanto os hieroglifos, mas não se mostram incompativeis com práticas democráticas modernas. Não servem hoje em dia para colocar os japoneses "em seus devidos lugares". Se é que algum dia serviram. Diante disso me parece que $O$ argumento de Ciro sobre o papel dos hieroglifos - cuja percepção pelo não-iniciado teria o papel de alocálos na hierarquia social - precisa ser refinado. Não é nem a natureza da escrita que gera a dominação social, nem mesmo a sua percepção imediata. 
A escrita não representava o fluxo discursivo: nela não há sequer recursos sintáticos. Não serviria portanto como instrumento generalizado de controle da ordem social: o que é mais óbvio ainda se nos lembrarmos de que, na civilização egípcia, não havia a prática de ensino escolar que disseminasse o saber sobre a escrita. O treinamento da sub-elite de escribas "parece ter sido vocacional, sob a supervisão de um superior" (Baines 1983:580). O distanciamento de propósitos ideológicos imediatos deve-se à função original da escrita que era controlar propriedade e registrar estoques. Assim, pouco importa se os atores sociais sequer vissem e muito menos entendessem a escrita. Também não podemos nos esquecer que a prática de um estado centralizado já existia antes da invenção da escrita (Baines 1988: 194). Portanto, se já existiam práticas políticas centralizadas e hierarquizantes, por que a escrita haveria de ter um papel fundamental na manutenção da ordem social? Principalmente quando se tratava de um recurso comunicativo de alcance restrito, e que, transposto para a arte monumental, me parece mais uma decoração.

Certamente a ordem social se mantinha por outros meios. A identificação de propriedade e de estoques pode perfeitamente estar fora do olhar e do entendimento público e ainda assim atingir plenamente os seus objetivos. A aparição pública de signos incompreensíveis para os atores sociais só virá depois como pompa e espetáculo, como afirmação e não instauração da hierarquia excludente, mostrando marcas de prestígios que articulavam valores sociais vividos no cotidiano.

É curioso notar que as fontes que primeiro apresentaram escrita e representação foram encontradas em objetos datados do quarto milênio A.C.: eram palhetas para tritura e mistura de cosméticos. Baines $(1989: 476)$ acredita que esses objetos participavam do que ele chama de sistema de decoro e que assim não tinham o propósito de expressão pública. $O$ sistema de decoro trazia consigo uma ideologia importante justamente pelo que escondia: enfatizava-se indirełamente a hierarquia já existente, e aceita de maneira generalizada.

Numa sociedade como a egípcia, onde os sujeitos orbitavam num concerto coeso, mas feito de exclusões, o que vinha do sistema de decoro jamais poderia ter uma função de controle ideológico, pois seu alcance era naturalmente restrito e limitado. No Egito antigo, a ação ideológica pública e coletiva só poderia ser oral. As rotinas sociais desprezavam a alfabetização. A pintura, as artes representacionais e a escrita não iam além da elite (Baines 1988:2051, porque não era mesmo preciso.

Para os egípcios, talvez os monumentos públicos corporificassem o poder estatal. Ainda que a conclusão possa parecer razoável, fica a pergunta: como saber de fato? Sendo a ideologia política oral, por que, na civilização egípcia antiga, o poder político funcionou tão eficazmente e por tanto tempo? Temos um problema real para a interpretação de Ciro Flamarion, já que quase nada nos permite sequer uma olhadela na ideologia dos que estavam à margem da elite e qué, talvez, possam até ter sustentado valores opostos e conflitantes com a classe dominante, mas que desconhecemos. Em nenhum período da história égípcia, há prova significativa de uma contra-cultura (Baines 1988:207). 
Apesar de tudo, acho que Ciro Flamarion tem boa chance de estar certo. Suas inferências seriam ainda melhores se tivéssemos mais documentos e registros - sempre signos - que fornecessem evidência para as hipóteses sobre a função da arte na sociedade egípcia. É claro que nunca há uma apreensão direła da história. A rigor tudo é mediatizado por signos que são mais do que reflexos. Os signos são elementos produtores na vida social. Ciro Flamarion não tem saída, a não ser fazer inferências a partir de um conjunto de signos. Quanto mais signos, melhor. Em última análise, signos - prioritariamente signos conferirão validade às interpretações históricas.

Então, por que os historiadores são tão resistentes ao estudo dos signos? Muitos acreditavam, de maneira preconceituosa, que história e semiótica são completamente incompatíveis. Mas, no desenvolvimento da história da arte podemos encontrar esforços de sintetização das perspectivas históricas e semióticas, conflitantes apenas na superfície. Muito antes de Ginzburg, Alois Riegl defendera uma abordagem de teor semiótico para a história da arte. Naquilo que Margaret lversen (1972) chamou de a primeira fase de Riegl, ele procurara aplicar os princípios da neo-gramática à historiografia das artes visuais. Segundo Riegl, a tarefa do historiador seria examinar os estilos artísticos com o propósito de isolar as leis históricas que os formavam: há, aqui, um visível paralelo com a lingüistica da época que se definia como o estudo comparativo das transformações das línguas, ordenando-as numa presumida série histórica. Lingüísticas ou visuais, as formas desenvolvem-se organicamente, conforme um plano oculto que é histórico.

Mais tarde, a história da arte tomaria os mesmos rumos da lingüistica. Para lingǘstica a princípio, e posteriormente para a história da arte, as análises sincrônicas seriam consideradas prioritárias, em detrimento das abordagens diacrônicas. Tanto Wölfflin como Riegl acentuavam que os elementos estilísticos da arte seguiam relações constantes, tomando a forma de um sistema. Esse sistema teria, então, o mesmo princípio contratual que a ordem lingüística, cujas convenções são partilhadas pela comunidade de atores sociais. Novamente, como já observei em relação à dupla face do kantismo, que se define simultâneamente por uma concepção teleológica da história e por um contratualismo convencionalista, passa-se de uma seqüencialidade linearizada para um modelo contratual e convencionalista. Assim, o estudo daquilo que parece estritamente histórico é substituído por uma análise das partes que compõem o sistema que funciona como um conjunto orgânico de leis ou de convenções (lversen 1972:62). O discurso historiográfico aproxima-se de Saussure ${ }^{6}$, cujas teses sobre as formações lingüísticas assemelham-se às de Alois Riegl sobre a história dos estilos artísticos (Iversen 1972:66).

O que talvez crie uma incômoda crise de identidade para os estudos históricos. A prioridade passara a ser a interpretação das convenções de uma época que presumidamente homogeneizam as imagens produzidas nesse momento histórico. A história é, então, infestada por uma ideologia convencionalista. A crítica que Panofsky fez a Riegl não o liberou completamente do convencionalismo dominante em todas as ciências humanas. Em todos esses
6 . Norman Bryson (1983:XII) disse que os caminhos da história da arte devem passar necessariamente por Saussure. Ora, só haverá alguma novidade na recomendação para quem desconhecer a já antiga herança saussuriana na teoria da arte que foi transmitida por Riegl a Panofsky. 
7. As teses de Lowe oscilam entre o determinismo rígido e a trivialidade ao afirmar que a cultura sublinha e enfatiza os nossos hábitos perceptivos. $\mathrm{O}$ argumento de Lowe presume a ação historicamente determinada dos diversos meios de comunicação como o traço organizador das percepções. O resultado é por demais esquemático. casos, o problema não é a semiotização da história, mas o tipo de semiótica adolada sem questionamento mais intenso.

Argumentos empíricos contra o convencionalismo

A partir de agora devo discutir com algum detalhe a pertinência de argumentos convencionalistas na definição da imagem. Caso contrário, as respostas a Ulpiano e a Eduardo Peñuela Cañizal ficariam truncadas. É bem verdade que o convencionalismo sublinha também o trabalho de quem não é historiador. Ao atacar o iconismo como uma concepção ingênua, filha de um parentesco misterioso entre representamens e representados, Umberto Eco 11976:191-216), que é um semioticista, toma o lado dos convencionalistas. Para Eco, a conexão entre expressão e conteúdo resulta estritamente de um código - ou seja, de um sistema de regras correlacionais - estabelecido convencionalmente, produto de um elo cultural. A mesma posição é defendida por Nelson Goodman (1976) em Languages of Art, onde ele diz que uma imagem jamais pode ser caracterizada por analogia, por similaridade, ou por ser representação icônica. Gêmeos são semelhantes, mas não podemos dizer que um seja imagem representativa do outro (Goodman 1972: 146).

A imagem é produto de convenções, de hábitos, de ensino cultural, de regras partilhadas. Reconhecemos semelhanças e analogias porque fomos treinados para tal. As imagens precisam ser lidas, até mesmo aquelas feitas por perspectiva, que só para os ingênuos é supostamente natural; e a habilidade de leitura deve ser adquirida (Goodman 1976:14).

A analogia depende de convenções minuciosamente integradas em nossas percepções. Certo de que se trata de uma verdade indiscutivel, Nelson Goodman (1972:437), diz que só existem convenções. A similaridade é uma impostura, uma falsidade da qual devemos nos afastar. À primeira vista, o estilo de argumentação de Goodman é encantador e engenhoso, mas simplesmente falso. A iconicidade e a analogia são condições da estruturação neurológica que guia a percepção de imagens. Se olharmos com cuidado o argumento de Goodman, veremos que o recurso aos gêmeos vicia a sua exposição. Gêmeos não são imagens um do outro devido à sua característica de referentes: desde o início, jamais poderiam postular ao estatuto de imagens.

Ulpiano Bezerra de Meneses aproxima-se dessa idéia - que quase chega a ser um lugar-comum entre as ciências humanas - ao citar com aprovação Lowe (1982) e sua hipótese de que as estruturas perceptivas sejam históricas, e portanto culturalmente produzidas ${ }^{7}$.

Analistas defensores do convencionalismo acreditam apoiar-se em evidências etnográficas. No caso de Goodman, a extensão da evidência é mínima. Goodman (1976:15) cita como argumento, numa nota ao pé-de-página, as generalizações de Melville J. Herskovits em Man and his works a propósito das dificuldades de nativos em reconhecer fotografias de casas, pes- 
soas e paisagens. A fotografia seria uma interpretação convencionalizada daquilo que a câmara nos leva a ver.

Mitchell 11986:65), insiste em dizer que Goodman tem a seu lado a observação freqüente de etnógrafos que afirmam ser o reconhecimento de imagens possível apenas para aqueles que aprenderam a nomenclatura da representação, ou seja a convenção que as gerou. Ainda que o convencionalismo extremado pareça uma verdade óbvia e indiscutível, argumentarei contra ele. E assim espero atender à exigência, feita por Ulpiano, que pede um embasamento mais explícito para a minha hipótese de que existe uma fundamentação biológica que antecede a história e a cultura na percepção e na geração de formas visuais.

Num trabalho anterior (Neiva 1992:62-79), examinei as teses do convencionalismo extremado que nos vêm de Herder; Humboldt, Cassirer até Barthes na sua aula inaugural do Collège de France, quando ele diz que a língua é um exercício de poder, um poder fascista que não proíbe o discurso, mas nos obriga a ele. Um produto mais significativo da tradição convencionalista é a hipótese Sapir-Whorf que afirma tanto a singularidade de cada cultura como admite que as convenções formadoras das práticas culturais determinam a percepção, a cognição e os atos humanos.

Ainda que em suas variantes oscile entre influência e determinismo cultural - o que é problema teórico - a hipótese Sapir-Whorf enfatiza que as estruturas lingüísticas criam o real. Sua grade simbólica e seus sistemas de convenções refazem o mundo aparentemente objetivo, sem obedecer a uma relação de necessidade. Trata-se - é óbvio - de um kantismo que se desvia um pouco das teses de Kant, mas que postula uma metafísica imanente a cada sistema de convenções culturais que a priori moldam a experiência humana. Não há experiência da realidade fora dos sistemas de convenções. Como conjunto de convenções arbitrárias, a língua tudo estrutura e determina. Fora dela, o vazio: se é que há sequer o vazio. Assim, as formas lingüísticas indo-européias interiorizam sujeito e objeto, criando uma idéia de tempo como dimensão interior, ao passo que os Hopi pensam o tempo como acontecimento porque esse é o modo de sua estruturação lingüística. Tudo resulta da segmentação que o sistema simbólico impõe ao empírico.

Muitas pesquisas partiram das teses de Sapir-Whorf, seja para comprová-las experimentalmente, seja para expandi-las e aperfeiçoá-las. Dentre esses, é digno de nota o texto de Du Toit (1966) que comenta experimentos sobre a habilidade perceptiva em três dimensões dos Bantus, procurando através da hipótese Sapir-Whorf explicar os resultados dos testes aplicados por W. Hudson (1960, 1962 a 1962b). Du Toit acredita que os sistemas de convenção lingüística sejam um anteparo que conduz a percepção. Qualquer diferença perceptiva deve ser atribuída a modos distintos de aprendizado cultural.

Os pressupostos das teses da relatividade lingüística estão ali presentes e mais importante é a presunção de que uma morfologia cognitiva a priori de cunho cultural e lingüístico atua no reconhecimento das formas percebidas. No caso dos Bantus, Du Toit acredita que o reconhecimento perceptivo de imagens em três dimensões é deficiente porque na língua Bantu inexiste representação 
lingüistica de profundidade e também porque a classificação de objetos nessa cultura obedece a uma taxonomia ordenada pela cor do gado e pela forma de seus chifres, um tipo de classificação estranha ao modelo europeu (Du Toit 1966:60).

Ainda que Nelson Goodman não faça referência aos testes de Hudson, caso fossem definitivos, eles forneceriam evidência empírica para as teses convencionalistas. Deregowski (1968) observara, com graves conseqüências para a validade das afirmações de Du Toit, que os resultados de inabilidade de pecepção em três dimensões poderiam ser derivados do modo pelo qual os testes foram aplicados, fazendo com que muitos dos testados não fossem capazes de organizar o material do experimento.

Nos testes de Deregowski com crianças centro-africanas em idade escolar e empregados domésticos, o resultado é paradoxal: a maioria significativa de pessoas que não percebera as representações bi-dimensionais de Hudson mostrava-se capaz de construir modelos tri-dimensionais. Tudo está de acordo com leach (1975) que levanta a hipótese de que o problema dos testes de Hudson esteja na própria constituição da pesquisa. Os modelos de Hudson seriam ambíguos e confusos, dando margem a respostas desencontradas. No final das contas, Deregowski sustenta os mesmos princípios subjacentes aos testes de Hudson: o problema nesses testes residiria no material empregado. De maneira geral, as hipóteses condutoras dos experimentos de Hudson permaneceriam válidas, pois a representação pictórica por meio de pistas visuais depende de convenções, que não seriam necessárias para a identificação de profundidade em modelos tri-dimensionais (Deregowski 1968:203). Os africanos vêem objetos físicos em três dimensões, mas seriam incapazes de reconhecer imagens bi-dimensionais em profundidade porque as imagens dependem de convenções que a sua cultura não thes ensina.

Leach tomou vários cuidados negligenciados por Hudson. Em primeiro lugar, valeu-se de modos diferenciados de representação, usando em conjunção tanto desenhos vazados como fotografias, além de representações lineares que incorporavam gradações tonais. A sua hipótese principal era de que, se as crianças fossem instruídas corretamente, haveria um maior índice de acertos na percepção de imagens (Leach 1975:458). Afinal cuidou-se de fazer com que um africano nativo aplicasse o teste, usando a língua local: 0 dialeto padrão das crianças Shona que é o chizeruru. Acreditava-se que assim se evitaria o sentimento de intimidação, inibição ou mesmo temor de juízo negativo por parte de brancos que materializariam a figura do dominador. Os testes seriam precedidos das explicações necessárias para o reconhecimento de imagens em três dimensões. Era também crucial o uso combinado de imagens, tais como fotografias e as formas de desenho. A combinação de imagens com informação visual variada e a apresentação de instruções claras produziu um índice de $94 \%$ de acertos. O resultado falsifica os pressupostos convencionalistas. Ver uma imagem é produto de percepção e de interpretação correta das informações visuais por ela oferecidas. $O$ que fica bem claro no modo pelo qual o teste fora aplicado, não restringindo-se à identificação de que o objeto na representação estaria mais próximo do outro. As crianças testadas também deviam 
responder à seguinte pergunta: "por que você disse isso?". Sem a devida instrução, o índice de acertos caía para $46 \%$. E o que certamente é curioso: imagens com mais informação foram identificadas com maior precisão. Os índices de acertos de desenhos lineares chegavam a $62 \%$, enquanto que os de desenhos com linha e gradação de tom eram corretamente identificados $67 \%$ das vezes. $\bigcirc$ acerto em fotografias subia para $71 \%$, logo a fotografia que é considerada pelos convencionalistas como uma extensão técnica das convenções que fazem a perspectiva.

A cultura nativa não é certamente um elemento definitivamente condutor na percepção de imagens. Imagens são representações que oferecem pistas à percepção. A cultura certamente ajuda, mas não pode ser considerada como determinante na visão. Ainda que outros argumentos mais tarde se façam necessários, reafirmo a convicção de que as imagens se aproximam das condiçōes neurológicas da visão. As imagens não são arbitrárias, a menos que se queira dizer que as imagens não são o mundo exterior. Ora, a crítica é tão óbvia que nem sequer merece maiores comentários.

Num gesto que pode ser considerado de audácia, digo que a idéia vale até para imagens que supúnhamos com alto grau de arbitrariedade convencional. Gombrich (1983:193), que também entende a visão como um fluxo de informações obtidas por nossos movimentos pelo meio-ambiente, acredita que isso acontece no caso de desenhos egípcios antigos. Ao movermo-nos extraímos as invariantes do ambiente, sua disposição estruturante, sem considerarmos nenhum ponto de vista particular. Assim as representações dos desenhos egípcios não seriam jamais produtos de convenções arbitrárias, mas uma indicação da realidade que não está presa a nenhum momento ou situação. Os desenhos egípcios postulam condiçōes naturais da visão - um tipo de visão possivel - e nunca poderiam ser ditos arbitrários. Esses argumentos - que Gombrich extrai de Gibson (1971 \& 1979) - deveriam levar a uma reformulação da concepção histórica sobre a arte egípcia. A interpretação histórica ortodoxa parece estar presa a preconceitos injustificados, enfatizados por uma visão de estratificação social rígida e excludente que, se é verdade na análise da interação políitica, pode ser um equívoco no caso das imagens.

Representações em perspectiva, desenhos de crianças, pinturas egípcias antigas têm em comum o fato de que mostram uma forma visual que indica características invariantes. A imagem nunca é apenas uma forma pictórica, mas uma parada de dados óticos que informam o meio-ambiente. É do olhar humano - enquanto condição para nos movermos no mundo - e não de convenções arbitrárias que sai esse arranjo de invariantes estruturais em relação direta com o meio-ambiente. O que não quer dizer cópia ponto-a-ponto. Prefiro dizer que se trata de uma substituição aproximada. Toda imagem apresenta uma configuração de informaçōes invariantes que the permite especificar mais do que sua forma visual e assim apontar para o mundo exterior.

Presunções convencionalistas como as de Sapir-Whorf - até mesmo a versão complementar de Bryson (1983:31), que diz ser "a percepção um processo históricamente condicionado" - não só me parecem implausíveis, como acredito que haja evidência que as falsifique. 
Cito, como exemplo, um experimento radical registrado por Hochberg \& Brooks (1962) que procurava estabelecer se um menino - que jamais tenha recebido treino no reconhecimento de objetos representados pòr fotografias ou desenhos lineares em duas dimensões - poderia identificá-los em imagens. Ensino e treinamento seriam vitais se imagens fossem efetivamente construídas segundo uma nomenclatura a ser decifrada. Desde o nascimento da criança, os pais restringiram o seu acesso a imagens: o que implica uma ausência de treinamento na identificação de imagens designativas. Durante aproximadamente um ano e meio, o bloqueio fora quase total. A criança só teria visto algumas poucas imagens: uma gravura japonesa num dos quartos da casa, por onde ele freqüentemente atravessava; possivelmente os cartazes publicitários espalhados pelas estradas por onde ele viajara; durante seis vezes, mas - por acidente - ele teria manipulado um livro com imagens, o qual os pais retiraram de suas mãos sem estardalhaço; uma ou outra olhadela no rótulo de um pote de comida de bebê; um de seus brinquedos tinha estampado desenhos de duendes; e o espaldar de sua cadeira de comer tinha um decalque de bebê: a imagem no decalque ele só poderia tê-la visto de relance ao ser arrumado na cadeira. Em nenhum desses casos, seus pais o instruíram ou fizeram a menor menção de que os desenhos designariam coisas (Hochberg \& Brooks 1962:626).

Aos 19 meses, a vigilância começa a se mostrar impraticável. Dois incidentes levam os pais a suspender a abstinência de imagens. Acidentalmente, a criança vê a imagem de um cavalo na televisão e grita - feliz por reconhecê-lo - "cachorro". O menino vira-se para o decalque no espaldar de sua cadeira de comer e reconhece "bebê".

Os testes começam com a apresentação de 21 desenhos montados em cartões de $3 \times 5$ polegadas. A criança vê desenhos lineares vazados antes de qualquer fotografia: $O$ que se quer é evitar a inferência a partir da percepção de fotografias, que seriam representações mais próximas das condições naturais da visão. As respostas foram gravadas em tape. logo depois, a criança recebeu um número considerável de livros ilustrados. Agora, ela podia ter acesso mais livre a imagens, mas ainda assim evitou-se que a criança assistisse filmes e programas de televisão que poderiam fornecer instrução implícita para o reconhecimento de figuras. Diante de tentativas de reconhecer as imagens, os pais não demonstraram nenhuma reação. A designação restringia-se a objetos físicos, com o propósito exclusivo de construir um vocabulário sem imagens. Repetiu-se 0 teste anterior. Novamente as respostas foram gravadas. Duas pessoas que não participaram de todo esse processo serviram de árbitros para jutgar a correção das respostas da criança.

Hochberg \& Brooks (1962:628) concluem que, após os testes, a criança mostrou-se capaz de identificar corretamente a maioria das representações de objetos sólidos sem treinamento específico e sem instrução. Mesmo sendo uma análise restrita a uma criança, não há dúvida que após conhecimento do teste é impossivel sustentar - como proposição afirmativa universal - qualquer afirmação estritamente convencionalista a respeito de imagens. Se é possível identificar imagens sem treino e aprendizado, as imagens não são produto 
exclusivo de convenções: o que faz parecer exageradas as suposições de dificuldades em reconhecer imagens por parte de nativos que não tenham sido treinados nas convençães representacionais do ocidente.

Por que excluir processos perceptivos analógicos da constituição de imagens? Afinal, imagens são condicionadas à existência das condições de visão. $\bigcirc$ ícone está aquém das convenções. A dominância do convencionalismo é um paradigma empiricamente insustentável. Muitos o aceitam porque os pressupostos convencionalistas têm o estatuto corrente de lugar-comum na atual teoria da imagem. Como negar que a experiência relatada por Hochberg \& Brooks falsifica qualquer definição da imagem como sendo estritamente convencional?

Recuso qualquer insinuação de que esteja eu defendendo uma concepção ingênua a propósito da imagem, semelhante àquela que Bryson (1983) define como "atitude natural", ou mesmo suas derivações chamadas de "cópia essencial" e "perceptualismo". O fato de que a percepção não seja um processo determinado históricamente não quer dizer que exista necessariamente "um acesso direto entre consciência e mundo exterior" (Bryson 1983:31). A analogia é uma ação de signos, que - sendo duplicação analógica na retina e no córtex visual - permite a memória. Se a arbitrariedade das convenções nos leva a relativizar as culturas humanas, o iconismo orgânico também nos ensina que a espacialização de origem predatória é herança presente nos homens. Pois é a iconicidade que permite à mente animal antecipar os movimentos da presa. E mesmo que nos homens a predação seja atenuada por simbolizações culturais, que exercem sobre nós um controle feito a partir das representações codificadas coletivamente, vejo nisso algo de nobre que revela uma verdade quase sempre oculta e que nos situa como parte do mundo natural.

A história não pode ser apenas convenções. Sendo memória, há de ser também icônica e - aparentada aos exercícios de predação. Parece-me mais instigante imaginar a história a partir de uma nova origem, situada na coordenação animal predatória. Estamos próximos das exigências feitas por Ulpiano Bezerra de Meneses - a história como o relato de descontinuidades, reciclando todas as formas de produção de imagens, uma prática de poder, de produção, de circulação, de interdição, de compulsoriedade, enfim nos moldes da conflagração e da luta. Os pressupostos convencionalistas nos levam à paz dos cemitérios. Cabe aos historiadores nos dizer como é possível uma nova história. Os pés inventarão o caminho.

Argumentos teóricos contra o convencionalismo

Eduardo Peñuela Cañizal é um outro tipo de convencionalista. Não foi fácil chegar a tal conclusão. À primeira vista, Peñuela Cañizal é diretamente afiliado a princípios greimasianos8, cuja concepção de imagem é a de textoocorrência, efeito de acordo com regras culturais/Greimas \& Courtés 1983:226|. Assim para Greimas - e para Peñuela Cañizal - a imagem é feita
8. Peñuela Cañizal não só participou do elenco de tradutores do Dicionário de Semiótica de Greimas, como também, contribuiu com um ensaio interessante sobre Picasso para um volume em homenagem a Greimas (Peñuela Cañizal 1985:611-23). 
por conotações sociais subjacentes que produzem em quem a contempla uma espécie de ilusão referencial. São teses nitidamente convencionalistas. Mas, por outro lado, Peñuela Cañizal também diz que no jogo de vaivém característico da imagem, existem "indices pulsionais que determinam a presença do corpo". Não acho que em si seja impossível conciliar tais perspectivas - uma convencionalista; a outra, corporal - tão aparentemente contraditórias. Mas, como Peñuela Cañizal não vê além do convencionalismo logocêntrico que o inspira, ele acaba transformando a imagem num texto bastardo, numa presença material que é apenas sub-produto de convenções, da linguagem, da intratextualidade, se preferirmos. Por que motivo, Peñuela Cañizal 11985:611), na sua análise de uma Weeping Head de Picasso; definiria o quadro como "texto visual" ? Não é à toa que, em nota num artigo mais recente, Peñuela oscila entre condenar a similaridade icônica e concordar com uma possível reformulação do conceito de iconicidade (Peñuela Cañizal 1990:274). Porque defendo uma idéia de conhecimento radicalmente falivel e conjectural, concordo com Eduardo: em todo problema há mais de uma solução. Para os que discordam, há sempre a alegria de combater o bom combate.

Assim Peñuela examina o meu artigo e toma um outro caminho. Meus equívocos seriam efeito da incapacidade de entender a imagem como objeto simbólico. Após afirmar que "a imagem se apresenta como um objeto simbólico em que o efeito de referente e o efeito de designatum se confundem", meu crítico reclama de mim uma distinção entre designatum e referente. Suspeito que Peñuela queira nos levar a uma posição ainda mais extremada: pois na prática acabaríamos subsumindo toda e qualquer referência à dimensão convencionalista do designatum.

Se eu fosse um convencionalista excludente - como Peñuela é - certamente adotaria a fórmula que the parece mais óbvia e até mesmo necessária. Mas, não sendo um convencionalista, recuso-me a contribuir ainda mais para a supremacia do simbólico nas ciências sociais e humanas.

De forma alguma nego a dimensão simbólica. Minha crítica vai para aqueles que só vêem a convencionalidade. Lamento desapontar a Peñuela, mas descarto a categoria de designatum. Antes de apresentar os meus motivos, tenho a obrigação de expor brevemente esse conceito que parece um "abre-te-sésamo" para Eduardo Peñuela Cañizal, mas que infelizmente não foi exposto com detalhe e muito menos contextualizado.

O conceito de designatum foi apresentado por Charles Morris na sua contribuição à International Encyclopedia of Unified Science, editada por ele, Otto Neurath e Rudolf Carnap. No seu texto -Foundations of the theory of signs - Morris (1938) defende a idéia de que na ação sígnica, na semiose, estão envolvidos um fundamento que age como signo, um objeto ao qual esse fundamento se refere, além da geração de um efeito no intérprete. Em virtude desse efeito, o objeto em questão é um signo para o intérprete. A maneira pela qual Morris define semiose o leva a entendê-la não como uma operação sígnica, mas como uma ação de alcance psicológico ou comportamental, já que repousa nos efeitos sobre o intérprete. Além dos três elementos, identificados por Pierce, que comporiam a função-signo, haveria um quarto integrante do 
processo: o intérprete (Morris 1938:81). No modelo de Morris, o objeto - o referente - se transforma no que ele chama de designatum.

Ao negar a singularidade do objeto, Morris faz com que existam apenas modos de representação interagindo nos intérpretes. Nesse modelo, existem prioritariamente representações com maior ou menor grau de convencionalidade. Assim, a referência ao mesmo objeto não significa que os signos tenham os mesmos designata. O que leva Morris (1938:83) a dizer: "um signo pode ter um designatum, mas óbviamente todo signo de fato não se refere a um objeto necessariamente existente".

A referência transforma-se no fantasma de uma representação. Tudo é muito próximo daquilo que Nelson Goodman - outro convencionalista extremado - afirmava em sua distinção entre representação-de e representação-como. A representação de algo supõe uma existência factual, enquanto que a representação-como refere-se a uma classe denotada. A imagem de um homem concreto seria tanto a representação desse homem como a representação da categoria homem em geral: "uma imagem que represente um homem o denota; a imagem que representa um homem ficcional é uma figura-de-homem (man-picture)" Goodman 1976:27-8).

A gramática das representações denota-se a si própria. Porque vemos não um evento, mas as condições de sua representação - em última análise suas convenções - a imagem pode ser uma representação universalizante sem estar presa à descrição de particularidades. A imagem denota uma classe de objetos: é um termo-de-classe que representa uma generalidade. Basta ler como Morris (1938:83) define designatum, para classificá-lo como um convencionalista bastante aproximado de Nelson Goodman: "designatum não é uma coisa, mas uma classe de objetos - e essa classe pode ter muitos membros, um membro ou nenhum membro".

Tenho dificuldade em entender porque Peñuela Cañizal exige uma distinção entre objeto e designatum. Morris faz mais do que distinguir referente e designatum. Ele transforma a referência - o denotatum - em efeito do designatum, que seria um tipo ou uma classe de objetos. Confundem-se irremediavet mente a indicação de um existente com uma representação geral. A queixa de Peñuela só se justifica como estratégia no sentido de permitir-the uma manobra verbal justificadora de seus pressupostos convencionalistas. $\bigcirc$ mais surpreendente é que Peñuela prefere desconhecer o fało de que o próprio Morris (1946:258), mais tarde, repudiará a noção mágica de designatum, sob pressão da crítica de George V. Gentry (1941).

Pensando bem, parece-me que sem a idéia de designatum o modelo de Morris se aproximaria mais da dimensão corporal tão insistentemente mencionada por Peñuela. Pois, ao postular designatum como classe ou tipo de objeto, Morris defende o conceito paradoxal de objeto simbólico que, por ser gerado por convenções, não teria jamais a singularidade que é o traço do objeto e também do corpo. Após abandonar o designatum, Morris (1946) vai afirmar que há, nos signos, uma propriedade de indicadores que dispara respostas comportamentais, sugerindo um nexo neurológico entre os signos e as ações humanas. O signo deixa de ser convenção e é reconcebido como fenômeno neuro-cortical: ou seja, fenômeno do corpo. 
Há uma barreira intransponivel entre o convencionalismo excludente e a dimensão do corpo. $O$ convencionalismo transfigurou o que seria singular em generalidade. Para Gentry (1941:382), fica bem claro que o termo designatum refere-se a uma posição ou função simbólica. E assim, Morris jamais poderia estar falando em classe de objetos como coleção de objetos com traços comuns, pois implicaria a intromissão de existências singulares em seu modelo teórico exclusivamente generalista. O que Morris faz é uma mera acrobacia verbal que esconde, numa manobra nominalista e voluntariosa, 0 fato de que - no conceito de designatum - abrigam-se duas forças contraditórias capazes de se anular mútuamente. Como pode o objeto ser geral e simultâneamente singular? Assim, num gesto de elegância e dignidade, o conceito de designatum acabou sucumbindo às críticas. Não vejo, portanto, como sustentar uma distinção entre designatum e referência já que seu criador a abandona como um estorvo.

Quanto a Peñuela, fica um mistério: o que ele quer dizer quando afirma tão enfáticamente que os pressupostos fundadores da glossemática são indispensáveis para entender a relação das imagens com o corpo? Para Peñuela, corpo é uma metáfora vaga que hospeda idéias inquietas e indefinidas. O que só é mesmo claro se nos referirmos a outros ensaios do autor. Vejamos o que, em Duas leituras semióticas, Peñuela Cañizal diz sobre a palavra mágica corpo. Ao comentar o que ele chama de "texto artístico", Peñuela (1977:10) presume que se trała de "uma espécie de corpo, único, mas cheio de caminhos e lugares imprevistos, nunca totalmente descobertos. Um corpo que se retorce em mim a cada leitura e invade com sua presença áreas minhas relegadas pela entorpecente transparência da história cotidiana ao silêncio mais escuro. Por isso, o prazer de chegar até os lugares do texto, depois de percorrer com passos lentos alguns dos seus caminhos, deixa em não sei que parte de mim um sabor de sussurro e um gosto úmido de grito reprimido." A citação é longa e de tão pessoal me parece impenetrável.

Graças a um movimento estilístico, que é argumentar narrando na primeira pessoa, Eduardo Peñuela descreve o que the causa o "texto artístico". Se Peñuela quer dizer que as leituras causam reações difusas e individuais em quem as lê, trata-se de uma luminosa banalidade, que vale tanto para "textos artísticos" como para exames de laboratório.

Suspeito que Peñuela almeje algo mais: enunciando um ponto de vista de modo tão solipsista, ele evitará a falsificação de seu texto. $O$ argumento é solipsista porque o autor é um eu ideal de conhecimento. Parece-the que nada mais importa: os efeitos que ele registra em si mesmo apresentam-se como a única realidade. Tudo o que não está nesse eu ideal é não mais do que a sua sombra. Por serem baseados num eu ideal e inquestionável, os argumentos solipsistas resistem à falsificação. Ao falar de corpo, Peñuela fala de si mesmo. A princípio não há o que contra-argumentar. Resta-nos aceitar ou não os seus argumentos. Entretanto, há coisas que preciso dizer. Não compreendo como pode 
possa qualificar-se como chave para o entendimento do corpo que é uma singularidade intransponível, ainda mais no caso de sua opção solipsista. Talvez haja aí um motivo que me escapa e que, de qualquer maneira, permanece oculto.

Num texto recente, Peñuela (1990) analisa quadros de Picasso e pergunta-se o que neles há de ilusão visual. Ao falar de imagens ambíguas que apresentam objetos impossiveis, cujas formas se alteram sob o nosso olhar, afundando-se na distância, ou salientando-se na direção contrária, Peñuela (1990:272-3) apresenta uma explicação solipsista tão extremada quanto o seu convencionalismo: "posso dizer, finalmente, que sinto (quase com surpresa) as imagens fantasmáticas de mim mesmo, ao olhar para o desenho (...). Imagens imaginárias de mim mesmo representadas na escuridão de minhas retinas pelas ilusões visuais que as linhas fascinantes desse trabalho provocam em mim" 9 .

Um argumento assim não pode ser considerado conhecimento sobre o corpo: é uma narrativa pessoal, um simples ato de enunciação poética. Todo conhecimento é público, coletivo e assim pode ser submetido à crítica. Qualificá-lo de conhecimento pessoal - que seria a alternativa tolerante ao que Peñuela faz - é uma contradição em termos.Pelo menos para mim, no que concerne o corpo, os caminhos que meu crítico aponta levam a lugar nenhum.

Será que esse conhecimento é possivel? Se a única dimensão biológica for a do corpo pessoal, e se é impossivel uma teoria da percepção com base biológica estável, comum a todos os homens - como Ulpiano chega até a sugerir - então Peñuela teria razão em optar pela pessoalidade mais extrema em seus argumentos. Mas a presunção é insustentável. Citada por Ulpiano em seu comentário, Carolyn Bloomer (1990:212) argumenta que, se por um lado, na percepção de imagens, existe uma atuante presença relativizadora das convenções culturais, isso não exclui que várias características perceptivas sejam universais, como por exemplo," a constância perceptual, as percepções de forma e de fundo, cor, espaço e movimento". Uma teoria dos signos que aspire à complexidade da experiência tem por obrigação enfrentar a dimensão biológica. É imprudente rejeitá-la por puro preconceito, sem exame detalhado.

História e convenção, ordem biológica e analogia

Apesar de ser um pouco mais do que um leitor desse assunto, acredito que devamos abrir os ouvidos para o que vem de experimentos recentes no campo da psicologia cognitiva. Existe uma dimensão anterior ao observador histórico do qual Ulpiano nos fala.

Pesquisas recentes (Farah 1988 \& 1990; Kosslyn 1980\& 1988) partem do princípio que a produção de imagens mentais resulta de uma operação de armazenamento de informações. O processo não é instantâneo, mas gradual. E nesse processo a analogia, enquanto forma relacional básica de cunho biológico, é o princípio regente. Na verdade, é uma produção de analogia o que permite com que uma imagem armazenada seja associada a outra. Cabe agora expor o que poderia ser entendido como sutileza: por analogia
9. Há mais do que reações pessoais e subjetivas no reconhecimento da representação de objetos impossíveis.

Parece que pessoas com lesões cerebrais que produzem agnose associativa são incapazes de reconhecer o desenho desses objetos. Existe pelo menos um relato clínico do problema (Ratcliff \& Newcombe 1982).

Ver um objeto até mesmo a construção imaginária de representações paradoxais - depende de nossa estruturação biológica e não da subjetividade. Farah (1990:58-143) discute com detalhe o que seja agnose associativa. Um dos exemplos apresentados é o de um paciente de meia-idade que sofreu lesão cerebral após a queda aguda de pressão sanguinea. $\mathrm{O}$ paciente manteve a sua capacidade lingüística, mas não consegue reconhecer a maioria dos estímulos visuais. Caso não possa nomear o objeto, o paciente não o descreve, nem mesmo consegue demonstrar o seu uso. Portanto, um estetoscópio transforma-se em "uma corda 
comprida com algo redondo na ponta: seria um relógio?" (Farah 1990:58).A atençâo do espectador diante de um objeto impossível flutua porque a imagem apresenta informações ambíguas para todos aqueles que a vêem. $\mathrm{O}$ fenômeno é objetivo e nada tem a ver com a subjetividade do espectador. não me refiro a uma concepção ingênua da representação onde prevalece uma correspondência do tipo ponto-a-ponto.

Analogia é representação num sentido mais complexo. Por analogia podemos fazer com que uma forma - uma configuração visual - substitua outra: é uma operação sígnica como aquela que leva crianças a cavalgar o cavalinhode-pau. No belo estudo de Gombrich (1965) - que dá título ao livro Meditations on a hobby horse - fica claro que a criança realiza uma analogia formal, não com o cavalo real, mas a partir de um processo de substituição aproximada entre signos. A substituição se dá porque alguns traços do cabo de vassoura e da imagem do cavalo apresentam-se como análogos. Substitui-se graças ao reconhecimento de funções analógicas, e não por correspondência ponto-aponto entre o cavalo e o cabo de vassoura.

A analogia permite a troca de uma imagem por outra e assim chegamos ao objeto. Gombrich 11993:69) formula o seguinte paradoxo: talvez o mundo nunca se assemelhe a uma imagem, mas uma imagem pode ser feita de modo a parecer-se com o mundo. Na analogia, um representante age como se fosse um outro de maneira aproximativa, possivel e parcial.

Kosslyn (1988: 1623) apresenta cinco razões pelas quais as imagens aparecem gradualmente: 1 las formas das partes individuais de um objeto são agrupadas em isolamento; 2las relações espaciais entre as partes são armazenadas em separado das formas; 3/as relações espaciais especificam a localização específica face a outras partes; 4las partes armazenadas são usadas para a formação de imagens mentais; 5Jum ponto de referência numa parte anteriormente identificada pode ser localizado de cada vez.

Uma importante revelação dos experimentos de Kosslyn é a de que imagem visual não é imediatamente dada. Trata-se de uma construção parcial, resulfante da decomposição da percepção em partes. A decomposição é feita por analogia e assim estocada. A relação entre os componentes armazenados se faz também por analogia. Na nossa atividade mental, as imagens não estão sempre presentes; elas acontecem em determinadas circunstâncias e não vêm instantaneamente ao cérebro. A base desse fenômeno é neurológica e foi observada por Martha J. Farah (1990) em seu estudo sobre agnosia visual que registra a perda de imagens mentais em pacientes com lesões cerebrais.

Nos testes de Kosslyn também notamos que imagens mais complexas - ou seja, aquelas com mais detalhes e informação visual - exigem mais tempo para serem evocadas, porque, quando as imagens são vistas pela primeira vez, elas sã̃o estocadas individualmente $e$, ao serem reativadas, a seqüência é também parcial e individualizada. Talvez, além das aplicações defeifuosas dos testes de Hudson, a suposta dificuldade dos nativos de culturas não-ocidentais em reconhecer imagens deva-se mais ao fato de não terem sido expostos à contemplação dessas figuras do que qualquer barreira criada por convenções culturais.

Mantenho sem hesitação que a operação analógica tem um fundo neurológico, pois os sistemas corticais são o que determinam o reconhecimento de formas e permitem a localização de objetos no espaço. Para Kosslyn (1988:1622), as células dos dois sistemas corticais são sensíveis a estímulos 
visuais, mas têm propriedades funcionais distintas. As células no lóbulo temporal inferior são sensiveis ao reconhecimento de cores e de formas - sendo altamente sintonizadas para a identificação de formas específicas - e têm campos receptivos amplos que, na maioria das vezes incluem fóvea.Por outro lado, as células no lóbulo parietal não são sensíveis às formas, não têm fóvea, mas são sensíveis ao movimento e à localização dos objetos no espaço. A remoção do lóbulo temporal traz consigo obstáculos para a discriminação de formas, mas ainda assim é possivel a localização de objetos. Por outro lado, a remoção do lóbulo pariental afeta a localização, mas o reconhecimento de formas permanece inalterado.

Concluímos, então, que a analogia antecede às convenções. $\bigcirc$ reconhecimento de uma imagem depende da estruturação neuro-cortical. Não é de nossa ordem cultural, mas de nosso arranjo biológico. Até mesmo a codificação, que nos permite localizar a imagem guardada, depende de operações analógicas. É justamente graças à analogia que as variantes de uma forma, tais como um objeto movendo-se no espaço, são agrupadas como invariantes na memória. Caso aquilo que foi codificado não corresponda analogicamente ao que é visto, não haverá reconhecimento. Não vejo como se pode defender a convencionalidade pura e simples.

Representações retinotrópicas interagem analogicamente a partir do que fora armazenado no córtex visual. $\bigcirc$ que há aqui é ação sígnica, pois o objeto visto é transposto, decupado e seccionado em outros estímulos, mas que retém as relações analógicas. Tyle (1991) acredita que seja como se numa folha de borracha desenhássemos junções e relações, e logo após a esticássemos, distorcendo o desenho original. Não haverá mais correspondência pontoa-ponto. Entretanto, tanto antes como depois de esticarmos a folha, temos o mesmo número de partes e de relações, ainda que a forma aparente tenha sido alterada (Tyle 1991:36). O fundamento operativo da imagem é icônico e préconvencional.

\section{A história reinventada}

Sem maiores problemas admito que a concepção convencionalista tenha sido muito útil para um determinado tipo de história. Agora, devemos nos perguntar porque é necessário questionar o que vêm dando certo já há tanto tempo. O motivo é simples: esse tipo de história fossilizou-se. A noção de convenção serviu porque com ela podíamos situar a imagem num quadro de interpretação possivelmente válido para os membros da cultura que a gerou. Afinal a imagem artística fora vista e consumida por um conjunto concreto de atores sociais. Era legítimo para o historiador inferir que houvesse também um conjunto de comportamentos homogêneos repondendo à imagem. A homogeneidade não era sequer discutida, pois acreditava-se que a especificação histórica e cultural autorizava a presunção. É claro que existiam relações gerais e identificáveis entre a imagem e a audiência para a qual ela foi produzida (Summers $1981: 1121$. 
10. Ginzburg (19896.50) diz claramente que na composição da historiografia moderna estão presentes duas tradições intelectuais distintas: a historiografia clássica e a pesquisa antiquária.
Como havia um conjunto de relações homogêneas que ligavam a obra à sua época, por que não reduzir a imagem a um fenômeno de arquivo, cujo principal guardião é o historiador; e seu templo, o museu? Assim a mentalidade histórica de antiquário é criada e considerada como a postura natural10. Os historiadores encontrarão prazer no alinhamento de arquivos e cronologias. Seu ofício é estabelecer séries conexas. Acredito que seja a razão pela qual Ulpiano Bezerra de Meneses vê as análises de Saxl e Panofsky como exemplos admiráveis de um tipo de história, cuja qualidade está numa " notável organização documental".

No abrigo seguro do museu, materializa-se uma história empenhada em negar as teorias semióticas que aspirem à diversidade da experiência (Kuspit 1987:346).

É dever da história fugir do signo como se admitito fosse uma profanação daquilo que the tem sido mais sagrado. A teoria dos signos que os historiadores adotarem será aquela que methor justifique esses pressupostos fossilizantes, e no caso aquela que for estritamente convencionalista.

Na minha opinião trata-se de um grave equívoco. Nem mesmo a possibilidade de uma constância perceptiva de cunho biológico é ameaça para o fato de que a história seja uma realidade da interação humana. A história tem a força do que é inegável. A historicidade é inquestionável. $O$ que discutimos é a maneira pela qual interpretamos, abordamos e narramos a historicidade. Mesmo que fosse o contrário, qual o problema em reformar um campo de estudos seja lá ele qual for? Por que essa fobia de preservar-se pura, intacta e. sacralizada? Ainda que a preço do questionamento de seus pressupostos disciplinares, a história - a rigor, nenhuma das humanidades - pode dar-se ao luxo de ignorar o fundamento biológico de nossa morfogênese animal. A constância do aparelho sensorial antecede a história. De uma maneira radical, é a partir dela que existem soluções históricas diferenciadas.

Não esqueçamos que Gombrich produziu uma admirável abordagem histórica da imagem, mantendo-se à distância de posturas estritamente convencionalistas. Muitas avaliações tendem a consideráto em sua primeira fase - a de Arte e ilusão (1960) - como um convencionalista. Pois - em Arte e ilusão - ele mesmo falara numa nomenclatura da linguagem pictórica. Lendo-o com cuidado, vemos que Gombrich adotara desde o início uma posição mais sutil. Para muitos que o viram como um convencionalista, destruidor de conceitos de uma estética antiquada, as afirmações posteriores de Gombrich 11972 , 1975 \& 19811, já não tão ambíguas e nitidamente críticas do convencionalismo, seriam um desapontamento.

Dos antigos admiradores de Gombrich, Krieger (1984) não o perdoa. Como pôde Gombrich negar o que para Krieger é a sua maior realização: ter solapado definitivamente a discussão de como a imagem representa a "realidade", ou melhor, como os espectadores e membros de uma audiência percebiam uma representação e a relacionavam com suas versões da realidade? A partir de agora, a teoria da arte não mais precisava falar em imitação, analogia e semelhança. Tínhamos um novo vocabulário para falar de questões estéticas. Para que retornar a esses termos antiquados? As imagens 
são o produto exclusivo de convenções pictóricas. $\bigcirc$ olho sofre a ação da cultura e está "sempre em estado de inocência perdida" (Krieger 1985:505) ${ }^{11}$.

Por sua vez, Gombrich (1985) jura que se trata de um mal-entendido. A discussão sobre a relação analógica entre a imagem e o real estivera sempre presente nas suas preocupações. De fato, inexiste o confronto que Krieger presume entre dois momentos em Gombrich, um no qual ele seria o humanista cético e outro, no qual prevaleceria o cientificista reacionário. Em Arte e ilusão, Gombrich refletira o tempo todo como a imagem é a construção de um esquema visual tentativo que sofre correções, num processo de tentativa e erro, comparação e ajuste, semelhante ao falsificacionismo científico defendido por Karl Popper.

Será que esse presumido perceptualismo nega a dimensão histórica? A mim me parece que não. A teoria do esquema visual e suas correçōes é essencialmente histórica: As transformações e as correções de um esquema visual indicam unidades estilísticas abrangentes para um determinado período histórico ou então rupturas ou mesmo renascimentos. Permanece a historicidade da obra. Em si mesmo, o fluxo histórico não faz sentido se não há a transformação de algo que fora uma vez concebido como permanente.

Deixei para tratar dos comentários críticos de Lucrécia D'Alessio Ferrara no final de minha resposta. Quero terminar tendo o prazer de concordar com ela. É com acuidade que Lucrécia percebe que na arquitetura do texto está a imagem de sua estrutura argumentativa. Esse detalhe que Lucrécia D'Alessio aponta é de vital importância.

De fato, não há anacronismo algum em escolher Charles Sanders Peirce para prover alternativas aos impasses criados por Cassirer e por Panofsky, ainda que Peirce seja cronologicamente anterior tanto ao filósofo das formas simbólicas como ao iconólogo. O tempo que preside a uma argumentação é um tempo lógico e não estritamente cronológico. Assim procuro fugir da tirania das séries conexas. Quero estar livre das cronologias rigidamente lineares para as quais o tempo sucedè-se como a seqüência dos relógios. A história é mais do que uma ordem linear: ela é interação, presença de todas as complexidades, da configuração biológica e da cultura, onde agem todos os processos sígnicos, da analogia à convenção. A tarefa é imensa.

Assim, Peirce passa a ser um autor de hoje e não apenas um representante da filosofia pragmatista americana do final do século XIX. É a imagem de uma história viva, bem capturada por Ulpiano Bezerra de Meneses quando, em seu comentário, ele se pergunta se as imagens africanas são coisa de branco ou de negro. Da mesma maneira, Peirce é um autor de ontem ou de hoje? De ambos, diria Ulpiano e com ele eu concordaria.

A renovação da história virá quando pudermos tornar as séries conexas não um caminho traçado por réguas, mas uma rede capaz de exprimir, capturar, interpretar e dar conta de múltiplos sentidos. Se para tal for preciso abandonar os modelos que herdamos da historiografia tradicional, por que não? A possibilidade de mudança e de substituição no fundo me apazigua.

Em seu comentário, Lucrécia D'Alessio Ferrara define Peirce como "um lógico da produção de conhecimento alravés da experiência". A frase é precisa e indica-o como alternativa ao convencionalismo. Quando muito, as teo-
1 1. Imagino qual terá sido a reação de Krieger ao ler um artigo posterior de Gombrich (1988:31), onde se encontra a idéia de que as teses convencionalistas que tornam a imagem aparentada com a escrita impedem que entendamos um quadro em sua relação direta com a natureza, num processo análogo à extração de informações do meio ambiente. 
rias convencionalistas escavam as condições da experiência e afastam-se da complexidade das significações vividas. A vida que os signos revelam não pode ser uma dimensão que a história negligencie. Lucrécia conclui corretamente que defendo a idéia de que história e semiótica sejam campos contíguos. E mais: que poderão ser uma unidade se for possivel entender a semiótica como uma proposta de revisão da história.

O que será possivel se dispusermos de uma teoria dos signos moldada conforme uma categoria fundamental da experiência que é a ação sígnica. É da consciência de como os signos agem que virá a reinvenção da história. $O$ diálogo está apenas começando. 
RUBIO CARRACEDO, José. El bombre y la ética. Barcelona, Anthropos. 1987

SAHUINS, Marshall. Cultura e razão prática. Rio de Janeiro, Zahar. 1979

SAUSSURE, Ferdinand de. Curso de Linguistíca Geral. São Paulo, Cultrix. 1974

SCHAFER, Heinrich. Principles of Egyptian art. Oxford, Griffith Institute. 1986

SAXL, Fritz. A beritage of images. Harmondsworth, Penguin. 1970.

SCHUTTE, Anne Jacobson. Storia notturna: una decifrazione del Sabba, by 1992 Carlo Ginzburg (book review). Journal of Modern History, 64:575-6.

SERCOVICH, Armando. Presentación. In: PEIRCE, Charles S. La Ciencia de la 1974 Semiótica. Buenos Aires, Nueva Vision.

SOARES, Lícia. A imagem vista através das tricotomias peirceanas. 1991 Comunicação \& Sociedade, 17:115-128.

SOPPELSA, Robert T. Western art-historical methodology and African art: 1988 Panofsky's paradigm and Ivorian Mma. Art Journal, 47:14753.

STERN, Paul. The problem of history and temporality in Kantian ethics. 1986 Review of Metaphysics, 39:505-45.

STERN, Randolph. Vendo a cultura numa sala para um príncipe renascentista. 1992 In: HUNT, Lynn. orgs.

SUMMERS, David. Conventions in Art History. New Literary History, 1981 13(1):103-123.

'THOM, René. Les mathématiques et l'intelligible. Dialectica, 29:71-80. 1975.

THOM, René. Matbematical models of morpbogenesis. Chichster, Ellis 1983 Horwood.

TYLE, Michael. The imagery debate. Cambridge and London, The MIT 1991 Press.

WILKINSON, Richard H. Reading Egyptian art. London, Thames \& Hudson. 1992. 


\section{BIBLIOGRAFIA GERAL}

ALLEN, Thomas George. ed. e trad. The book of the dead or going forth by 1974 day. Chicago, The University of Chicago Press, pp. 183-185 (Encantamento 175).

ARGAN, Giulio Carlo. História da arte como bistória da cidade. São Paulo, 1992 Martins Fontes.

BAINES, John. Communication and display: the integration of early Egyptian 1989 art and writing. Antiquity, 63:471-82.

BAINES, John. Literacy, social organization and the archeological record: the 1988 case of early Egypt. In: State and society: the emergence and development of social bierarchy and political centralization. edited by John Gledhill, Barbara Bender and Morgens Trolk Larsen. London, Unwin Hyman.

BAINES, John. Literacy and Ancient Egyptian Society. Man, 18:572-599.

1983.

BAUD, Marcelle. Le caractère du dessin en Egypte ancienne. Paris, Adrien1978 Maisonneuve.

BAYO MARGALEF, José. Percepción, desarrollo cognitivo y artes visuales. Barce1987 lona, Anthropos.

BLAZER, Kent. Clues, myths and the historical method (book review). The 1991 Historian, 53:541-2.

BLOOMER, Carolyn. Principles of visual perception. New York. Design 1990 Press.

BRYSON, Norman. Vision and painting: the logic of gaze. New Haven and 1983 London, Yale University Press.

BRYSON, Norman. Looked of the overlooked. Cambridge, Harvard University 1990 Press.

BRYSON, Norman. Semiology and visual interpretation. In: BRYSON, Norman, 1991 Michael Ann Holly \& Keith Moxey, orgs. Visual theory, Painting and interpretation. Oxford, Polity: 61-73.

BURKE, Peter. Miti, emblemi, spie: morfologia e storia (book review). Journal 1990 of Modern History. 62:108-10.

CALABRESE, Omar. A linguagem da arte. Lisboa, Presença. 
CARDOSO, Ciro Flamarion Santana. Semiótica, História e classes sociais. In: 1988 Ensaios racionalistas. Rio, Campus: 61-92.

CASSIRER, Ernest. The pbilosopby of symbolic forms. vol.1: Language. New $1955 \mathrm{a}$ Haven, Yale University Press.

CASSIRER, Ernest. The pbilosopby of symbolic forms. vol. 2: Mythical $1955 \mathrm{~b}$ thought. New Haven, Yale University Press.

CASSIRER, Ernest. Linguagem e mito. São Paulo, Perspectiva. 1972.

CHARTIER, Roger. A História Cultural: entre práticas e representações. 1989 Rio, Difel/Bertrand-Brasil.

CHARTIER, Roger. O mundo como representação. Estudos Avançados, 11(5): 1991 173-191.

CRARY, Jonathan. Techniques of the observer. On vision and modernity in 1992 the 19th century. Cambridge, MIT Press.

CROW, Thomas. Painters and public life in 18th century. Paris, New Haven, 1985 Yale University Press.

DAVIS, Whitney. The canonical tradition in Ancient Egyptian art. 1989. Cambridge, Cambridge University Press.

DEMOLEN, Richard L. Clues, myths and the historical method (book review). The Sixteenth Century Journal, 21(4):739-40.

DEREGOWSKI, Jan B. Difficulties in pictorial depth perception in Africa. 1968 Journal of Psychology, 59(3):195-204.

DIDIER-HUBERMANN, Georges. Le parcours clos du danseur de corde, ou 1989 l'histoire de l'art dans les limites de sa simple raison: Les Cabiers du Musée National d'Art Moderne, 30:41-58.

DU TOIT, Brian M. Pictorial depth and linguistic relativity. Psychologia 1966 Africana, 11:51-63.

ECO, Umberto. A theory of Semiotics. Bloomington, Indiana University Press. 1976

FARAH, Martha J. The neurological basis of mental imagery: a componential 1984 analysis. Cognition, 18:245-72.

FARAH, Martha J. Visual agnosia: disorders of object recognition and what 1990 they tell us about normal vision. Cambridge and London, The MIT Press. 
FAULKNER, R.O. ed. e trad. The Ancient Egyptian coffin texts. Warminster 1978 Aris \& Phillips, vol.I, 229-233 (Encantamento 312).

FERRY, Luc e RENAUT, Alain. Pensamento 68. Ensaio sobre o anti-bumanis1988 mo contemporâneo. São Paulo, Editora Ensaio.

FISCH, Max. Peirce, semiotic and pragmatism. Bloomington, Indiana 1986 University Press.

FISCHER, Henry George. L'écriture et l'art de l'Egypte ancienne. Paris, 1986 Presses Universitaires de France, pp. 24-46.

FRANCASTEL, Pierre. Imagem, visão e imaginação. São Paulo, Martins 1987 Fontes.

FYFE, Gordon e LAW, John, orgs. Picturing power. Visual depiction and social 1988 relations. London, Routledge.

GENTRY, George V. Some comments on Morris's class conception of the desi1941 gnatum. The Journal of Philosophy, 41:376-84.

GIBSON, James J. The information available in pictures. Leonardo, 4:221971 35.

GIBSON, James J. The ecological approach to visual perception. Boston, 1979 Houghton Mifflin.

GIBSON, Kathleen R. \& Tim Ingold, orgs. Tools, language and cognition in 1993 buman evolution. Cambridge, CUP Press.

GINZBURG, Carlo. Clues, myths and the bistorical method. Baltimore and 1989a London, Johns Hopkins University Press.

GINZBURG, Carlo. Montrer et citer: la verité de l'histoire. Le Débat, 56:43$1989 \mathrm{~b}$ 54.

GINZBURG, Carlo. Checking the evidence: the judge and the historian. 1991 Critical Inquiry, 18:79-92.

GOMBRICH, E.H. Art and illusion. A study in the psychology of pictorial re1960 presentation. New York, Pantheon Books.

GOMBRICH, E.H. Meditations on a bobby borse. London, Phaidon. 1963

GOMBRICH, E.H. The "what" and the "how": perspective representation and the 1972 phenomenal world. In: logic and art: essays in bonor of Nelson Goodman, edited by Richard Rudner \& Israel Scheffler. Indianapolis and New York, Bobbs-Merill. 
GOMBRICH, E.H. Symbolic images: studies in the art of the Renaissance. 1975a London, Phaidon.

GOMBRICH, E.H. Mirror and map: theories of pictorial representation: In: $1975 \mathrm{~b}$ Philosophical Transactions of the Royal Society of London, 270:119-149.

GOMBRICH, E.H. Image and code: scope and limits of conventionalism in 1981 pictorial representation. In: Image and code, edited by Wendy Steiner. Ann Arbor, Michigan Studies in the Humanities: 1041.

GOMBRICH, E.H. Drawings from Ancient Egypt, by William H. Peck (book 1983 review). The Journal of Egyptian Archeology, 69:192-3.

GOMBRICH, E.H. Representation and misrepresentation. Critical Inquiry, 1985 11:195-201.

GOMBRICH, E.H. Voir la nature, voir les peintures. Cabiers du Musée 1988 National d'Art Moderne, 24:21-43.

GOMBRICH, E.H. Additional thoughts on perspective. The Journal of 1993 Aesthetics and Art Criticiam. 51(1):69.

GOODMAN, Nelson. Problems and projects. Indianapolis, Bobbs-Merill. 1972.

GOODMAN, Nelson. Languages of art: an approach to the theory of sym1976 bols. Indianapolis, Hackett.

GOULD, Stephen Jay. A escada e o cone: iconografias do progresso. In: Vida 1990 Maravilbosa: o acaso na evolução e a natureza da história. São Paulo, Companhia das Letras.

GREIMAS, A.J. \& COURTES, J. Dicionário de Semiótica. São Paulo, 1983 Cultrix.

GROTTANELLI, Vinigi L. The Lugard Lecture of 1961. In: African images: 1975 essays in African Iconology, edited by Daniel F.MacCall \& Edna G.Bay, New York \& London, Africana Publishing Co.p.322.

GROENEWEGEN-FRANKFORT, H.A. Arrest and movement. An essay on 1987 space and time in the representational art of the Ancient Near East. Cambridge (Mass.), Harvard University Press.

HERLIHY, David. Clues, myths and the historical method (book review). 1991 Journal of Interdisciplinary History, 21:501-2.

HOCHBERG, Julian \& Brook. Virginia recognition as an unlearned ability: a 1962 study of one child's performance. American Journal of Psychology. 75:624-8. 
HOLLY, Michael Ann. Panofsky and the foundations of art bistory. Ithaca, $1984 \quad$ Cornell University Press.

HUDSON, W. Pictorial depth perception in sub-cultural groups in Africa. 1960 Journal of Social-Psycbology, 52:183-208.

HUDSON, W. Pictorial perception and educational adaptation in Africa. $1962 a$ Psychologia Africana, 9:226-239.

HUDSON, W. Cultural problems in pictorial perception. South African Journal $1962 \mathrm{~b}$ of Science, 58:189-95.

HUNT, Lynn. org., A nova bistória cultural. São Paulo, Martins Fontes. 1992

INGOLD, Tim. Epilogue. Technology, Language, intelligence. A reconsidera1993 tion of basic concepts. In: gibson \& gold. orgs., 447449.

IVERSEN, Margaret. Style as structure: Alois Riegl's historiography. Art History, 1972 2(1):62-72.

JAKOBSON, Roman. Selected writings. II: Word and Language. The Hague, 1971 Mouton.

JENKINS, Keith. Re-thinking History. London, Routledge.

1991.

KANT, Immanuel. Ideas of a Universal History from a cosmopolitan point of 1959 view. In: Theories of History, edited by Patrick Gardiner, Glencoe, The Free Press.

KANT, Immanuel. Critique of pure reason. London, Macmillan. 1973.

KEIN, Philip J. Kant's political theory and philosophy of history. Clio, 1989 18(4):325-45.

KOSSLYN, Stephen M. Aspects of a cognitive neuroscience of mental imagery. 1988 Science, 240:1621-26.

KRIEGER, Murray. The ambiguities of representation and illusion: an E.H. $1984 \quad$ Gombrich retrospective. Critical Inquiry, 11:181-94.

KRIEGER, Murray. Optics and aesthetic perception: a rebuttal. Critical 1985 Inquiry, 11:502-8.

KUSPIT, Donald. Traditional Art History's complaint against linguistic analysis 1987 of visual arts. The Journal of Aestbetics and Art Criticism, 45:345-9. 
LEACH, M.L. The effect of training on the pictorial depth perception of Shona 1975 children. Journal of Cross-Cultural Psycology, 6(4):45770 .

LEVI, Giovanni. Les usages de la biographie. Annales ESC, 6:1325-36.

1989.

LEVI-STRAUSS, Claude. Le cru et le cuit. Paris, Plon.

1964.

LOWE, Donald M. History of bourgeois perception. Chicago, The University 1982 of Chicago Press.

LURIA, Keith. The paradoxical Carlo Ginzburg. Radical History Review, 1986 35:80-7.

MAIRET, Gérard. Le discours et l'bistorique: essai sur la représentation bisto1974 rienne du temps. Paris, Reperes-Mame.

MARTIN, John. Carlo Ginzburg: storia notturna: una decifrazione del Sabba 1992 (book review). Speculum, 67:148-50.

MICHALOWSKI, Piotr. Early Mesopotamian communicative systems: art, litera1990 ture, and writing. In: GUNTER, Ann C. ed. Investigating artistic environments in the Ancient Near East. Washington, Smithsonian Institution, pp. 53-69

MITCHELL, W.J.T. Iconology: image, text, ideology. Chicago, The Chicago 1986 University Press.

MORRIS, Charles. Foundations of the theory of signs. In: Foundations of the $1938 \quad$ Unity of Science: toward an International Encyclopaedia of Unified Science, v.I numbers 1-10, edited by Otto Neurath, Rudolf Carnap and Charles Morris. Chicago and London, The University of Chicago Press.

MORRIS, Charles. Signs, Language and bebavior. New York, Braziller. 1946.

NEIVA JR., Eduardo. Comunicação: teoria e prática social. São Paulo, 1991 Brasiliense.

NEIVA JR., Eduardo. Um inferno de espelbos: comunicação, cultura e mundo 1992 natural. Rio de Janeiro, Rio Fundo.

NEWBY, P.H. Warrior pharaobs. London, Faber \& Faber.

NUGENT, Christopher. Ecstasies: deciphering the witches Sabbath, by Carlo 1992 Ginzburg (book review). The Historian, 54:711-2. 
PÄCHT, Otto. Panofsky's Early Netherlandish Painting-II. Burlington Magazine, 1956 98:267-79..

PANOFSKY, Erwin. Early Netherlandish Painting: its origins and character. 1953 Cambridge, Harvard University Press. 2 v.

PANOFSKY, Erwin. Meaning in the visual arts. Harmondsworth, Penguin. 1970a.

PANOFSKY, Erwin. Architecture gotbique et pensée scholastique. Paris, 1970b Minuit.

PANOFSKY, Erwin. La perspective comme forme symbolique et autres essais. 1975 Paris, Minuit.

PANOFSKY, Erwin. Significado nas artes visuais. São Paulo, Perspectiva. 1976

PEIRCE, Charles S. Collected papers. Cambridge, Harvard University Press. 8v. 1960

PECK, William H. (texto) e ROSS, John G. (fotografias). Egyptian drawings. 1978 New York, E.P. Dutton.

PEIRCE, Charles S. ed. Studies in logic, by members of the Johns Kopkins 1983 University (1883). Amsterdam, John Benjamins.

PEÑUELA CAÑIZAL, Eduardo. Duas Leituras semióticas. São Paulo, Perspectiva. 1977

PEÑUELA CAÑIZAL, Eduardo. A visual metaphor of the Femina Amara. In: 1985 Exigences et perspectives de la sémiotique, edited by $\mathrm{H}$. Parret \& H.G. Ruprecht, Amsterdam/Philadelphia, John Benjamins: 611-23.

PEÑUELA CAÑIZAL, Eduardo. Visual illusions and intratextuality in Picasso's 1990 Picasso. Semiotica, 81(3/4):259-275.

PIPPIN, Robert B. Modernism as a pbilosopbical problem. Cambridge 1991 (Mass.), Basil Blackwell.

POMIAN, Krzystof. L'Ordre du Temps. Paris, Gallimard.

1984.

RATCLIFF, GRAHAM \& NEWCOMBE, Freda. Object recognition: some 1982 deductions from clinical evidence. In: Normality and pathology in cogniitve functions, edited by Andrew W.Ellis. London and New York, Academic Press:147-172.

RICOEUR, Paul. Le conflit des interprétations. Paris, Seuil. 1969. 